\title{
Removal of Arsenic, Chromium and Uranium from Water Sources by Novel Nanostructured Materials Including Graphene-Based Modified Adsorbents: A Mini Review of Recent Developments
}

\author{
Athanasia K. Tolkou, Ioannis A. Katsoyiannis and Anastasios I. Zouboulis * (D) \\ Department of Chemistry, Aristotle University of Thessaloniki, GR-54124 Thessaloniki, Greece; \\ tolkatha@chem.auth.gr (A.K.T.); katsogia@chem.auth.gr (I.A.K.) \\ * Correspondence: zoubouli@chem.auth.gr; Tel.: +30-231-099-7794
}

Received: 13 April 2020; Accepted: 2 May 2020; Published: 7 May 2020

check for updates

\begin{abstract}
Groundwater is commonly used as a drinking water resource all over the world. Therefore, groundwater contamination by toxic metals is an important issue of utmost concern for public health, and several technologies are applied for their effective removal, such as coagulation, ion exchange, adsorption, and membrane applications like reverse osmosis. Adsorption is acknowledged as a simple, effective and economic technology, which has received increased interest recently, despite certain limitations regarding operational applications. The respective scientific efforts have been specifically focused on the development and implementation of novel nano-structured adsorbent materials, which may offer extensive specific surface areas, much higher than the conventional adsorbents, and hence, are expected to present higher removal efficiencies of pollutants. In this paper, the recent developments of nanomaterial applications for arsenic, chromium and uranium removal from groundwaters are critically reviewed. Particularly, the use of novel composite materials, based mainly on hybrid metallic oxide nanoparticles and on composites based on graphene oxide (GO) (i.e., graphene-based hybrids), showed promising evidences to achieve efficient removal of toxic metals from water sources, even in full scale applications.
\end{abstract}

Keywords: nanostructured adsorbents; hybrid processes; graphene; arsenic; chromium; uranium

\section{Introduction}

Water pollution by toxic metals and metalloids (e.g., arsenic, copper, mercury, cadmium, lead, uranium, chromium) is nowadays considered a serious global environmental problem, especially for groundwaters. Even in concentrations in the $\mu \mathrm{g} \mathrm{L}^{-1}$ range, their presence in various water bodies is considered particularly dangerous for human health and hence, their maximum allowable concentration in waters is strictly regulated by international organizations (World Health Organization (WHO), US Environmental Protection Agency (EPA), EU). Therefore, the efficient treatment of contaminated waters for the removal of toxic contaminants is necessary to provide people with safe drinking water. In order to detoxify the polluted waters, various treatment techniques, such as coagulation-flocculation, lime softening, photocatalytic, chemical or biological oxidation, bioremediation, ion-exchange, reverse osmosis, and adsorption have been employed with different efficiency degrees, depending upon the specific applicable conditions [1].

Considerable interest has attracted the preparation and use of novel nanostructured adsorbent materials with average particle sizes below $100 \mathrm{~nm}$, expecting that their properties will be superior to those of conventional materials with structures of bigger size [2]. The application of nano-scaled adsorbents comprises a novel and promising technology, especially for toxic metals removal from 
water sources, because of their respective substantially higher surface areas, which may provoke higher reactivity and increased affinity, capacity and selectivity for different metals [3]. Recently, promising materials, i.e., activated carbons [4] and bamboo-based biochar/montmorillonite composites [5] have been used for oxoanions (i.e., pertechnetate) and anionic pollutant (i.e., nitrates) removal from aqueous solutions, respectively. The objective of this review paper is to summarize the recent developments of nano-structured materials, including graphene-based modified/hybrid adsorbents, applied particularly in the water treatment of arsenic, uranium or chromium removal from water sources, with specific emphasis given to groundwater treatment.

All the relevant compounds of the examined toxic metals have the characteristic of being present in waters as oxyanions, in $\mathrm{pH}$ relevant to ground/waters, i.e., 6.5-8.5. Arsenic is present in waters with two major valency states, i.e., either as trivalent $\mathrm{As}(\mathrm{III})$ or pentavalent $\mathrm{As}(\mathrm{V})$. As(III) cannot be easily removed by the application of conventional water treatment technologies; therefore, it is usually pre-oxidized to $\mathrm{As}(\mathrm{V})$, which in turn is usually present as the respective oxyanions of arsenic acid $\left(\mathrm{H}_{2} \mathrm{AsO}_{4}{ }^{-}\right.$or $\left.\mathrm{HAsO}_{4}{ }^{2-}\right)[6] . \mathrm{Cr}(\mathrm{VI})$ is present in waters mainly as chromate $\left(\mathrm{CrO}_{4}{ }^{2-}\right)$ or dichromate $\left(\mathrm{Cr}_{2} \mathrm{O}_{7}{ }^{2-}\right) . \mathrm{Cr}(\mathrm{III})$ is rather insoluble in aqueous solutions, easily forming precipitates and interacting with other co-existing constituents; therefore, it is quite seldom found in considerable concentrations [7]. $\mathrm{U}(\mathrm{VI})$ is present mainly as the uranyl cation $\left(\mathrm{UO}_{2}{ }^{2+}\right)$, which, in waters containing bicarbonate anions however, is most probably complexed and presented as $\mathrm{UO}_{2}\left(\mathrm{CO}_{3}\right)_{2}{ }^{2-}[8]$.

These oxyanions can usually be removed from waters by the application of different technologies, due to differences in their aquatic chemistry. Arsenic, in most cases, is firstly oxidized by means of chemical or biological oxidation and then removed by conventional coagulation (with Fe or $\mathrm{Al}$ based salts), or by adsorption on Fe-oxides or activated alumina, which is also a widely applied technology [1]. $\mathrm{Cr}(\mathrm{VI})$ is mostly removed from water by reduction using $\mathrm{Fe}(\mathrm{II})$, which reduces to $\mathrm{Cr}(\mathrm{III})$, which is subsequently removed usually by precipitation as insoluble hydrous hydroxides [9]. U(VI) is mostly removed by lime softening or adsorption onto iron oxides [8]. In several cases, these oxyanions have been simultaneously present in natural ground/waters and their adsorption on efficient adsorbents with extended surface areas could be a perfect solution, when considering their simultaneous removal.

Adsorption is a conventional technology which can have applications in the removal of all these toxic oxyanions and therefore, in this review, several novel nanostructured adsorbents are critically evaluated, in order to present their ability regarding the removal of these metals from ground/water sources.

\section{Nanostructure Materials for Arsenic Removal}

\subsection{Arsenic (As)}

Arsenic (As) is considered as a contaminant of major concern, due to its extreme toxicity at relatively low doses and its worldwide occurrence in groundwaters. It is mostly naturally present in groundwaters, but several industrial processes and products, such as wood preservatives, semi-conductors and agricultural applications (pesticides), may also introduce arsenic into the environment [10,11]. Increased arsenic concentration levels in groundwaters cause significant issues in the supply of secured drinking water [12], because long-term arsenic contaminated water consumption has been linked with various diseases such as several types of cancers [13]. As a result, the WHO [12] has reduced the acceptable concentration value for arsenic in drinking water from 50 to $10 \mu \mathrm{g} \mathrm{L}^{-1}$ and most countries also apply the same maximum allowed concentration [14].

Arsenic in natural waters is mainly found with its inorganic forms of $\mathrm{As}(\mathrm{III})\left(\mathrm{H}_{3} \mathrm{AsO}_{3}\right)$ and/or As(V) $\left(\mathrm{H}_{3} \mathrm{AsO}_{4}, \mathrm{H}_{2} \mathrm{AsO}^{4-}\right.$ and $\left.\mathrm{HAsO}_{3}{ }^{2-}\right)[15,16]$. The prevalence of these species in natural waters is mainly dependent on the existing oxidation-reduction conditions and $\mathrm{pH}$ values [17]. Under oxic conditions, the pentavalent form of $\mathrm{As}(\mathrm{V})$ is predominantly present as $\mathrm{H}_{2} \mathrm{AsO}^{4-}, \mathrm{HAsO}_{4}{ }^{2-}$ with $\mathrm{pKa}_{1}=2.19$ and $\mathrm{pKa}_{2}=6.94$, respectively. Conversely, when anoxic conditions prevail, e.g., in anaerobic groundwaters, 
$\mathrm{As}(\mathrm{III})$ is the main species found, which at $\mathrm{pH}$ values relevant to groundwaters is present as the non-ionic arsenous acid $\left(\mathrm{H}_{3} \mathrm{AsO}_{3}, \mathrm{pKa}_{1}=9.22\right)$ [7].

$\mathrm{As}(\mathrm{III})$ is less adsorbed than the $\mathrm{As}(\mathrm{V})$, when interacting with solid surfaces and, therefore, As(III) is less efficiently removed by the use of common treatment processes, such as adsorption and precipitation. To handle this problem, an oxidation stage is usually incorporated in the treatment train to convert $\mathrm{As}(\mathrm{III})$ to $\mathrm{As}(\mathrm{V})[15,16]$. Several studies have indicated that $\mathrm{As}(\mathrm{III})$ removal to concentrations less than $10 \mu \mathrm{g} \mathrm{L}{ }^{-1}$ by adsorption onto suitable adsorbent materials, such as iron oxides, is feasible [16,17], but requires relatively large quantities of the used adsorbent, which makes this method rather inadequate for full-scale applications.

Consequently, the development of more effective technologies to remove (particularly) the As(III) species from water sources is important. The use of nano-materials could serve as a viable alternative to provide more sustainable solutions, by offering extensive surface areas and using similar material quantity, leading potentially to enhanced As(III) removal without the need for the pre-oxidation step. In the following, the recent applications of newly synthesized nanomaterials, as applied for arsenic removal $[17,18]$, will be presented, showing - in certain cases-improved sorption capacity for As(III).

\subsection{Application of Hydrous Nanostructure Iron(III)-Titanium(IV) Binary Oxide for As(III) and As $(V)$ Removal}

Iron oxides are widely applied for arsenic removal from aqueous solutions [19]. The most recent developments include the incorporation of other metals into the structure of $\mathrm{Fe}(\mathrm{III})$ oxides to achieve increased efficiency, regarding arsenic removal. Gupta et al. (2008) [20] synthesized and used nano-structured hydrous Fe(III)-Ti(IV) bimetallic mixed oxides (NHITO) for the sorption of arsenic, because the incorporation of Ti(IV) was found to present enhanced material properties, namely surface sorption and photo-induced catalysis.

The ability of NHITO to remove arsenic from solution containing $50 \mathrm{mg} \mathrm{As(III)} \mathrm{L}^{-1}$ to the permissible concentration value (i.e., $0.01 \mathrm{mg} \mathrm{L}^{-1}$ ) was investigated with batch experiments at the $\mathrm{pH}$ value 7 , by varying the dose of solid/adsorbent, while maintaining the other parameters constant. It was found that the residual concentration was decreased to 6.30 from $50 \mathrm{mg} \mathrm{L}^{-1}$, when applying a sorbent dose of $2 \mathrm{~g} \mathrm{~L}^{-1}$. By substantially increasing the sorbent dose to $38 \mathrm{~g} \mathrm{~L}^{-1}$, the residual arsenic concentration $0.01 \mathrm{mg} \mathrm{L}^{-1}$ was achieved, corresponding to a relatively small sorption capacity of $1.3 \mathrm{mg} \mathrm{g}^{-1}[20]$.

Similarly to Zhou et al. (2008) [21], Gupta et al. (2008) [20] developed the mesoporous hybrid adsorbent $\mathrm{TiO}_{2} / \alpha-\mathrm{Fe}_{2} \mathrm{O}_{3}$. This material has the ability to convert $\mathrm{As}(\mathrm{III})$ to $\mathrm{As}(\mathrm{V})$ by photocatalysis and to adsorb the formed $\mathrm{As}(\mathrm{V})$ by the iron oxides, because it was found that the properties of both components and nanoparticles, i.e., the photocatalytic activity of $\mathrm{TiO}_{2}$ and the adsorptive feature of $\mathrm{Fe}_{2} \mathrm{O}_{3}$, remained quite unchanged in the composite form. The removal of As(III) was found to be linked directly with the $\mathrm{pH}$ value of water. In addition, Acry et al. (2011) [22] also synthesized $\mathrm{TiO}_{2} / \alpha-\mathrm{Fe}_{2} \mathrm{O}_{3}$ composite adsorbent material, by applying a simple precipitating technique and examined it for arsenic removal. The highest capacity was found to be $\mathrm{pH}$-dependent for this case, also.

\subsection{Application of Iron(III)-Copper(II) Binary Oxide for As(V) and As(III) Removal}

Recently, it was reported that cupric oxide was an effective sorbent for both As(V) and As(III) removals over a wide $\mathrm{pH}$ range values, relevant to drinking water treatment (i.e., for $\mathrm{pH}=6.6-8.6$ ), even in the presence of other competing anions, such as silica, sulfate and phosphate [23]. Zhang et al. (2013) [24] synthesized Fe-Cu binary oxides and evaluated their arsenic adsorption capacity. The results showed that the prepared $\mathrm{Fe}-\mathrm{Cu}$ binary oxide particles are actually formed by smaller nano-sized particles and are very effective for the elimination of $\mathrm{As}(\mathrm{V})$ and $\mathrm{As}(\mathrm{III})$ species from waters. The highest adsorption capacities for $\mathrm{As}(\mathrm{V})$ and $\mathrm{As}(\mathrm{III})$ are 83 and $122 \mathrm{mg} \mathrm{g}^{-1}$ at $\mathrm{pH} 7$, correspondingly. Owing to its exceptional arsenic sorptive performance, straightforward and efficient synthesis process, and effective regeneration of depleted adsorbent materials, the Fe-Cu binary oxide 
could serve as an adsorbent with promising application for both $\mathrm{As}(\mathrm{V})$ and $\mathrm{As}(\mathrm{III})$ species removal from water and wastewater [24].

Furthermore, this material shows increased capacity for As(III) sorption, which is very promising, because the problem with arsenic removal is that As(III) is usually less efficiently removed from waters by the application of conventional methods. Therefore, the application of such materials, showing increased As(III) sorption capacity, especially at the pilot-plant scale, would be very interesting and could show the potential of such methods to remove As(III) by circumventing the application of pre-oxidation step. Very recently, Jauckowicz-Sobala et al. (2020) [25] used these oxides (ratio Fe:Cu = 2:1) by depositing them onto polymer beads and showed that As(III) removal takes place through a two-step mechanism, namely catalytic oxidation and adsorption. The adsorptive ability was measured as $92 \mathrm{mg} \mathrm{As} \mathrm{g}^{-1}$ of adsorbent, close to that previously referred by Zhang et al. (2013). Due to the formation of polymer beads, column experiments were performed, showing efficient removal of As(III) (reaching final concentrations below $10 \mu \mathrm{g} \mathrm{L}^{-1}$ ) from quite high initial concentrations (up to $500 \mu \mathrm{g} \mathrm{L}^{-1}$ ).

\subsection{Application of Hierarchically Porous $\mathrm{CeO}_{2}-\mathrm{ZrO}_{2}$ Nanospheres for As(V) and As(III) Removal}

Hierarchically porous $\mathrm{CeO}_{2}-\mathrm{ZrO}_{2}$ nanospheres were synthesized by $\mathrm{Xu}$ et al. (2013) [26], and their suitability as arsenic sorbents was examined. The $\mathrm{CeO}_{2}-\mathrm{ZrO}_{2}$ hollow nanospheres showed strong affinity and selectivity to arsenic with an adsorption capacity of 27 and $9 \mathrm{mg} \mathrm{g}^{-1}$ for $\mathrm{As}(\mathrm{V})$ and $\mathrm{As}(\mathrm{III})$, respectively. These results were obtained at the equilibrium arsenic concentration of $0.01 \mathrm{mg} \mathrm{L}^{-1}$ under circumneutral $\mathrm{pH}$ values $(\mathrm{pH} 6.9 \pm 0.2)$. As $(\mathrm{V})$ removal could be so efficient as to achieve residual concentration below $10 \mu \mathrm{g} \mathrm{L}^{-1}$ (from starting $\mathrm{As}(\mathrm{V})$ concentrations $12 \mathrm{mg} \mathrm{L}^{-1}$ ) by the $\mathrm{CeO}_{2}-\mathrm{ZrO}_{2}$ nanospheric materials with an adsorbent dose of $0.2 \mathrm{mg} \mathrm{mL}^{-1}$, while for the case of As(III), this could be also reduced to below $10 \mu \mathrm{g} \mathrm{L}^{-1}$, but from As(III) concentrations of $1 \mathrm{mg} \mathrm{L}^{-1}$. Both cases are considered as very efficient, since the usual arsenic concentrations in groundwaters are much lower, i.e., between $20-500 \mu \mathrm{g} \mathrm{L}-1$. The significant adsorption capacity of $\mathrm{CeO}_{2}-\mathrm{ZrO}_{2}$ nanospheres is mainly due to the respective better pore accessibility and the abundant surface hydroxyl groups, participating to their substitution with arsenic species [26].

\subsection{Application of Graphene Oxide-Ferric Hydroxide $\mathrm{GO} / \mathrm{Fe}(\mathrm{OH})_{3}(\mathrm{GO}-\mathrm{Fe})$ Composites for As(V) Removal}

Graphene is a two-dimensional (2-D) nanosheet of graphite with one atom thickness; it was firstly found in 2004 by Geim and Novoselov [27], and since then, a wide range of applications has been exploited, e.g., in transparent conductors, field-effect transistors, fuel cells, batteries, solar cells, and water purifiers [28-30], as well as in the food industry [31]. Graphene holds some exceptional properties, for instance, extremely large specific surface area $\left(\sim 2600 \mathrm{~m}^{2} \mathrm{~g}^{-1}\right)$ and very strong chemical stability [27,32], making it an efficient material for use in the water industry, mainly as a support material, e.g., for the nano-scaled iron oxides, which were proven to be excellent adsorbents for the removal of arsenic [6].

Zhang et al. (2010) [33] developed a series of innovative composites, based on graphene oxide (GO) cross-linked with Fe-hydroxides with several $\mathrm{GO} / \mathrm{FeSO}_{4} \cdot 7 \mathrm{H}_{2} \mathrm{O}$ ratios, i.e., $\mathrm{GO}-\mathrm{Fe}-1$, $\mathrm{GO}-\mathrm{Fe}-2$, for the successful treatment of arsenic contaminated drinking water. GO was mainly used as a supporting substrate of ferric hydroxide, due to its several interesting properties, such as high mechanical strength, large surface area and simple preparation using inexpensive natural graphite.

The efficient $\mathrm{As}(\mathrm{V})$ sorption, using GO-Fe-5, was identified over a broad $\mathrm{pH}$ range, i.e., for $\mathrm{pH} 4-9$, and different initial $\mathrm{As}(\mathrm{V})$ concentrations $\left(0.5-20.0 \mathrm{mg} \mathrm{L}^{-1}\right)$, but the efficiency was decreased at $\mathrm{pH}$ values higher than 8 , where iron oxides exhibit a negative overall surface charge, which repulses the negatively charged arsenate species, such as $\mathrm{HAsO}_{3}{ }^{2-}[19,34]$. However, in all examined cases, the remaining Fe levels in the finished water were rather low $\left(<1.0 \mathrm{mg} \mathrm{L}^{-1}\right)$, indicating that iron stays mostly stable on the support material and can be further tested in pilot-scale applications, e.g., using continuous operating adsorption columns [33]. 


\subsection{Application of Magnetite $\mathrm{Fe}_{3} \mathrm{O}_{4}$-Reduced Graphite Oxide- $\mathrm{MnO}_{2}$ Nanocomposites for $\mathrm{As}(\mathrm{V})$ and As(III) Removal}

Luo et al. (2012) [35], in their study, combined the oxidizing ability of manganese dioxide, the large surface area of $\mathrm{GO}$ and the magnetic characteristics of $\mathrm{Fe}_{3} \mathrm{O}_{4}$, aiming at synthesizing a new adsorbent for arsenic, i.e., $\mathrm{Fe}_{3} \mathrm{O}_{4}$ and $\mathrm{MnO}_{2}$ nanoparticles modified $\mathrm{GO}\left(\mathrm{Fe}_{3} \mathrm{O}_{4}-\mathrm{RGO}-\mathrm{MnO}_{2}\right)$ nanocomposites. The preparation of this material was carried out by a two-stage precipitation reaction, starting with graphite oxide (GO) as the raw material, followed by the reduced $\mathrm{Fe}_{3} \mathrm{O}_{4}-\mathrm{RGO}$ as intermediate product, and forming finally a material with a specific area of $114 \mathrm{~m}^{2} \mathrm{~g}^{-1}$.

This adsorbent presents a high removal capacity towards both $\mathrm{As}(\mathrm{III})$ and $\mathrm{As}(\mathrm{V})$, i.e., $14 \mathrm{mg} \mathrm{g}^{-1}$ and $12 \mathrm{mg} \mathrm{g}^{-1}$, respectively (using a solution containing $\mathrm{NaAsO}_{2}$ and $\mathrm{Na}_{2} \mathrm{HAsO}_{4} \cdot 7 \mathrm{H}_{2} \mathrm{O}$ ), with specific emphasis given to the higher adsorption capacity of $\mathrm{As}$ (III). In addition, arsenic adsorption remained rather constant for a broad $\mathrm{pH}$ span between 2-10. The aforementioned adsorbent provides a prominent advantage that can be further separated from the treated water sample by the application of magnetic separation [36]. Consequently, from the pragmatic point of view, the $\mathrm{Fe}_{3} \mathrm{O}_{4}-\mathrm{RGO}-\mathrm{MnO}_{2}$ nanocomposites could serve as excellent adsorbents for treating arsenic polluted waters in the future [35].

\subsection{Application of Graphene Oxide-Hydrated Zirconium Oxide for As(V) and As(III) Removal}

Zirconium oxide is a generally applied inorganic substance that is chemically inert, non-toxic, and highly insoluble in water. It was stated that zirconium oxide demonstrated solid arsenic adsorption capacity, particularly for As(III) [37]. Luo et al. (2013) [38] described the use of GO as substrate to support zirconium hydroxide $\left(\mathrm{ZrO}(\mathrm{OH})_{2}\right)$ nanoparticles for the concurrent removal of As(III) and $\mathrm{As}(\mathrm{V})$ from aqueous solutions. The forming nanocomposites $\left(\mathrm{GO}-\mathrm{ZrO}(\mathrm{OH})_{2}\right)$ were prepared by the hydro-thermal co-precipitation reaction. It was observed that this material exhibited very high adsorption capacity for $\mathrm{As}(\mathrm{V})$ and $\mathrm{As}(\mathrm{III})$, i.e., 95 and $85 \mathrm{mg} \mathrm{g}^{-1}$, respectively, reaching the equilibrium within $15 \mathrm{~min}$. The obtained results showed that $\mathrm{GO}-\mathrm{ZrO}(\mathrm{OH})_{2}$ (ratio 1:100) is exceedingly effective for the concurrent elimination of $\mathrm{As}(\mathrm{III})$ and/or $\mathrm{As}(\mathrm{V})$ [38].

\subsection{Application of Nano-Scaled Activated Carbon Modified by Iron and Manganese Oxides for As(V) Removal}

Recent developments include the successful removal of arsenic by activated carbon altered by iron and manganese oxides [39]. According to this study, a microporous activated carbon was impregnated with iron, iron/cobalt and iron/manganese mixtures by applying a novel and simple impregnation method, used for the preparation of magnetic activated carbons containing $\mathrm{Fe}_{3}\left(\right.$ or $\left.\mathrm{Mn}^{2+}\right) \mathrm{O}_{4}$. The modified carbons were assessed for $\mathrm{As}(\mathrm{V})$ removal and showed enhanced capabilities. The best $\mathrm{As}(\mathrm{V})$ adsorption capabilities were obtained for the $\mathrm{Fe}_{3}-\mathrm{xMn}_{\mathrm{x}} \mathrm{O}_{4}$-modified activated carbon, where $\mathrm{Mn}$ ions were also integrated in the magnetite lattice. The inclusion of $\mathrm{Mn}$ influenced the textural properties of the carbon, which was concluded because of the decrease of the surface area, as well as of surface $\mathrm{pH}$ and the $\mathrm{pH}_{\mathrm{pzc}}$ values and the rise of crystallinity values. It was indicated that arsenate, considered to be a Lewis base, becomes selectively adsorbed through the creation of inner-sphere bidentate complexes on the modified carbon surface. The impregnation of activated carbon with Fe gave an increment of $\mathrm{As}(\mathrm{V})$ maximum adsorption capability $\left(\mathrm{Q}_{\max }\right)$ from about $4 \mathrm{mg} \mathrm{g}^{-1}$ (for the raw carbon) up to $11 \mathrm{mg} \mathrm{g}^{-1}$, while the inclusion of Mn caused an additional improvement in the adsorption capacity up to $19 \mathrm{mg} \mathrm{g}^{-1}$.

Table 1 shows the reviewed nanomaterials when utilized for removal of As(III) and As(V) from aquatic sources and provides some more information about their structural characteristics and applications in water treatment. As shown in this Table, most of the proposed materials are efficient at $\mathrm{pH}$ values around 7 , for the removal of both $\mathrm{As}(\mathrm{III})$ and $\mathrm{As}(\mathrm{V})$ species. It is worth noting that the $\mathrm{Fe}-\mathrm{Cu}$ binary oxide material was found to be effective for removing both $\mathrm{As}(\mathrm{V})$ and $\mathrm{As}(\mathrm{III})$ species, providing an adsorption capacity of $122 \mathrm{mg} \mathrm{g}^{-1}$ at $\mathrm{pH} 7$ for $\mathrm{As}(\mathrm{III})$, while the hierarchically porous $\mathrm{CeO}_{2}-\mathrm{ZrO}_{2}$ nanospheres showed an adsorptive ability of only $9 \mathrm{mg} \mathrm{g}^{-1}$ for the case of $\mathrm{As}(\mathrm{III})$. An increased 
adsorption capacity was achieved when graphene oxide was combined with hydrated zirconium oxide $\left(\mathrm{GO}-\mathrm{ZrO}(\mathrm{OH})_{2}\right)$ and the obtained adsorption capacity was found to be greatly increased (up to $95 \mathrm{mg} \mathrm{g}^{-1}$ ). The latter material presents also a substantially larger surface area $\left(421 \mathrm{~m}^{2} \mathrm{~g}^{-1}\right)$, when compared with the $30 \mathrm{~m}^{2} \mathrm{~g}^{-1}$ of $\mathrm{CeO}_{2}-\mathrm{ZrO}_{2}$ nanospheres. In addition, the $\mathrm{Fe}-\mathrm{Cu}$ binary oxides material presented specific surface area $282 \mathrm{~m}^{2} \mathrm{~g}^{-1}$.

Table 1. Novel nanostructured materials utilized for the removal of arsenic from waters.

\begin{tabular}{|c|c|c|c|c|c|c|}
\hline $\begin{array}{c}\text { Novel } \\
\text { Nano-Material }\end{array}$ & $\begin{array}{c}\text { Fe(III)-Ti(IV) } \\
\text { Oxide } \\
\text { (NHITO) }\end{array}$ & $\begin{array}{l}\text { Fe(III)-Cu(II) } \\
\text { Oxide }\end{array}$ & $\mathrm{CeO}_{2}-\mathrm{ZrO}_{2}$ & $\mathrm{GO} / \mathrm{Fe}(\mathrm{OH})_{3}$ & $\mathrm{Fe}_{3} \mathrm{O}_{4}$-RGO-MnO & $\mathrm{GO}-\mathrm{ZrO}(\mathrm{OH})_{2}$ \\
\hline $\begin{array}{l}\text { As species } \\
\text { removal }\end{array}$ & $\mathrm{As}(\mathrm{III})$ & $\mathrm{As}(\mathrm{V}) / \mathrm{As}(\mathrm{III})$ & $\mathrm{As}(\mathrm{V}) / \mathrm{As}(\mathrm{III})$ & As $(V)$ & $\mathrm{As}(\mathrm{V}) / \mathrm{As}(\mathrm{III})$ & $\mathrm{As}(\mathrm{V}) / \mathrm{As}(\mathrm{III})$ \\
\hline Application & Groundwater & $\begin{array}{l}\text { Simulated } \\
\text { Ground } \\
\text { water }\end{array}$ & $\begin{array}{l}\text { Contaminated } \\
\text { natural } \\
\text { water }\end{array}$ & $\begin{array}{l}\text { Simulated } \\
\text { drinking }\end{array}$ & $\begin{array}{l}\text { Simulated Ground } \\
\text { water }\end{array}$ & $\begin{array}{l}\text { Simulated } \\
\text { drinking }\end{array}$ \\
\hline $\begin{array}{l}\text { Pore size } \\
\quad(\mathrm{nm})\end{array}$ & 11 & 4.3 & 90 & - & - & 2.3 \\
\hline Dose $\left(\mathrm{g} \mathrm{L}^{-1}\right)$ & 2 & 0.2 & 0.2 & - & 0.005 & 0.5 \\
\hline $\begin{array}{l}\text { C initial } \\
\left(\mathrm{mg} \mathrm{L}^{-1}\right)\end{array}$ & 0.11 & 10 & 0.01 & 51 & 5 & 1 \\
\hline $\mathrm{pH}$ & 7.0 & 7.0 & 6.9 & $4.0-9.0$ & 7.0 & $2.0-7.0$ \\
\hline $\begin{array}{l}\text { Adsorption } \\
\text { capacity } \\
\left(\mathrm{mg} \mathrm{g}^{-1}\right)\end{array}$ & 0.1 & $83 / 122$ & $27 / 9$ & 24 & $12 / 14$ & $85 / 95$ \\
\hline $\operatorname{BET}\left(\mathrm{m}^{2} \mathrm{~g}^{-1}\right)$ & 78 & 282 & 30 & - & 114 & 421 \\
\hline References & $\begin{array}{l}\text { Gupta et al. } \\
\text { (2009) [20] }\end{array}$ & $\begin{array}{l}\text { Zhang et al. } \\
\text { (2013) [24] }\end{array}$ & $\begin{array}{l}\text { Xu et al. } \\
\text { (2013) [26] }\end{array}$ & $\begin{array}{l}\text { Zhang et al. } \\
\text { (2010) [33] }\end{array}$ & Luo et al. (2012) [35] & $\begin{array}{l}\text { Luo et al. } \\
\text { (2013) [38] }\end{array}$ \\
\hline
\end{tabular}

Table 2 provides the comparison of Langmuir monolayer sorption capacities between different adsorbents, when applied for the removal of arsenic (III or V). As can be observed by comparing the relevant data of Table 2 with those in Table 1, the sorption ability of the previously described nanostructured materials (Table 1) was generally substantially higher.

Table 2. Comparative results of Langmuir monolayer sorption capacity for arsenic using the aforementioned materials.

\begin{tabular}{|c|c|c|c|c|}
\hline \multirow{2}{*}{ Sorbent Material } & \multirow{2}{*}{$\mathrm{pH}$} & \multicolumn{2}{|c|}{ Langmuir $Q_{\max }$ Capacity (mg g $\left.{ }^{-1}\right)$} & \multirow{2}{*}{ Reference } \\
\hline & & As(III) & $\operatorname{As}(\mathrm{V})$ & \\
\hline Crystalline hydrous ferric oxide & 7.0 & 33 & 25 & Manna et al. (2003) [40] \\
\hline Crystalline hydrous titanium oxide & 7.0 & 32 & - & Manna et al. (2004) [41] \\
\hline Nanoscale zero valent iron & 7.0 & 3 & - & Kenel et al. (2005) [42] \\
\hline Nano- $\mathrm{TiO}_{2}$ & 7.0 & 60 & 37 & Pena et al. (2005) [43] \\
\hline Hydrous stannic oxide & 7.0 & 16 & 4 & Manna et al. (2007) [44] \\
\hline Akaganeite nanocrystal & 7.5 & - & 134 & Deliyanni et al. (2003) [45] \\
\hline
\end{tabular}

\section{Nanostructured Materials for Chromium Removal}

\subsection{Chromium (Cr)}

Chromium is an odorless and tasteless metallic element, and it can be found naturally in rocks, plants, soil and volcanic dust. The most widespread forms of chromium that appear in real waters are the trivalent and hexavalent species. $\mathrm{Cr}(\mathrm{VI})$ is 100 times more toxic than $\mathrm{Cr}(\mathrm{III})$, showing high carcinogenic, mutagenic and teratogenic action to biological systems [46]. Therefore, the Environmental Protection Agency (EPA) has set the maximum concentration limit of $0.1 \mathrm{mg} \mathrm{L}^{-1}$ for the case of total chromium in water, whereas the World Health Organization (WHO) has set a lower respective limit $\left(0.05 \mathrm{mg} \mathrm{L}^{-1}\right)$ in drinking water for $\mathrm{Cr}(\mathrm{VI})$ [47]. 
Chromium has been applied traditionally in the chrome plating of metallic surfaces, and also as an element in dyes and pigments, in steel, in the leather tanning process and as a wood preservative. It is frequently discharged to the environment, after the discarding of chromium-containing materials, or as a by-product of the industrial processes that use it. There are also demonstrated cases of chromium being released to the environment by leakage, poor storage or inadequate industrial waste disposal practices, causing severe anthropogenic groundwater contamination and human health problems [48]. The serious toxicity of $\mathrm{Cr}(\mathrm{VI})$ has attracted the attention of the scientific community and environmental associations, provoking an growing number of headlines and a general increase of public awareness. In that direction, on 1 July 2014, the US State of California adopted a lower Maximum Concentration Level (MCL) of $0.01 \mathrm{mg} \mathrm{L}^{-1}$ for the presence of hexavalent chromium in drinking water [49].

To reduce $\mathrm{Cr}$ concentration from contaminated water sources, various treatment methods, such as coagulation followed by filtration [9], adsorption and membrane filtration, have been successfully applied. Nevertheless, for each of these treatment methods, some constraints exist, and therefore, it is challenging to address the newly imposed concentration limits [50].

The effective removal of $\mathrm{Cr}(\mathrm{VI})$, usually involves its preliminary reduction to $\mathrm{Cr}(\mathrm{III})$. In the trivalent state, chromium instantly forms $\mathrm{Cr}(\mathrm{OH})_{3}$ or $(\mathrm{Cr}, \mathrm{Fe})(\mathrm{OH})_{3}$, which are both very insoluble. The fairly lower solubility of $\mathrm{Cr}(\mathrm{OH})_{3}$ and $(\mathrm{Cr}, \mathrm{Fe})(\mathrm{OH})_{3}$ is mainly responsible for the generally low $\mathrm{Cr}(\mathrm{III})$ concentrations in waters, lower than the drinking water standards over the entire $\mathrm{pH}$ range relevant to drinking water [51].

However, it would be very useful for the drinking water treatment plants if $\mathrm{Cr}(\mathrm{VI})$ could be efficiently directly removed by sorption onto suitable materials, without the need for preliminary $\mathrm{Cr}(\mathrm{VI})$ reduction. Therefore, the current research is focusing on the development of novel adsorbent materials, with superior performance/competence against the removal of $\mathrm{Cr}(\mathrm{VI})$.

\subsection{Application of $\mathrm{NiO}$ Nanoparticles for $\mathrm{Cr}(\mathrm{VI})$ Removal}

Nickel oxide nanoparticles $(\mathrm{NiO})$, as an adsorbent material, have been used to control the mobility of metal ions in the environment, because of their high surface area, low production cost and natural porosity for the removal of heavy metals from aqueous solutions [52]. In a recent study, Behnajady and Bimeghdar (2014) [53] synthesized $\mathrm{NiO}$ nanoparticles by a simple precipitation method, using sodium hydroxide, for the removal of $\mathrm{Cr}(\mathrm{VI})$ from aqueous solutions. The main parameters (i.e., starting concentration of $\mathrm{Cr}(\mathrm{VI})$, dose of material, initial $\mathrm{pH}$ value and temperature) were investigated, regarding their effect on adsorption capacity.

The results show that $\mathrm{NiO}$ nanoparticles with a mean size of $11 \mathrm{~nm}$ were efficient adsorbents for $\mathrm{Cr}(\mathrm{VI})$ with a reported adsorption capacity of $5 \mathrm{mg} \mathrm{g}^{-1}$ for the initial $\mathrm{Cr}(\mathrm{VI})$ concentration $20 \mathrm{mg} \mathrm{L}^{-1}$, by using $0.6 \mathrm{~g} \mathrm{~L}^{-1}$ of absorbent at $\mathrm{T}=30^{\circ} \mathrm{C}$. The $\mathrm{pH}$ variation under the aforementioned conditions, indicated that at the $\mathrm{pH}$ value of 4.7 the adsorption of $\mathrm{Cr}(\mathrm{VI})$ was the highest, approximately $98 \%$ [53].

\subsection{Application of Graphene Oxide Functionalized with Magnetic Cyclodextrin-Chitosan for Cr(VI) Removal}

A simple chemical bonding method to synthesize magnetic cyclodextrin-chitosan/graphene oxide (CCGO) was published in 2013 by Li et al. [54]. Cyclodextrins are cyclic oligosaccharides endued with a hydrophilic outer surface and a hydrophobic inner cavity, capable of developing inclusion complexes with a broad variety of guest molecules, certainly affecting their physicochemical properties [55]. Chitosan-based sorbents have exhibited relatively elevated sorption capacities for heavy metals, due to their high nitrogen content and porosity. On the other hand, graphene oxide (GO), comprising several oxygen-containing functional groups on its surface, shows high-level adsorption performance for metal ions, but cannot be easily separated from the finished water. Magnetic $\beta$-cyclodextrin-chitosan nanoparticles have attracted attention, due to their excellent properties, such as easy separation and elevated adsorption capability.

Thus, the magnetic $\beta$-cyclodextrin-chitosan/graphene oxide materials were formulated via a staged process, where the carboxyl groups of GO chemically react with the amine groups of magnetic 
$\beta$-cyclodextrin-chitosan with the subsequent creation of chemical bonds between GO and chitosan. It was found that the $\mathrm{Cr}(\mathrm{VI})$ adsorptive capacity of CCGO strongly depends on the surface charge concentration, as well as on the specific surface area, and the respective adsorption capacity was found to be $68 \mathrm{mg} \mathrm{g}^{-1}$ of $\mathrm{Cr}(\mathrm{VI})$ using the CCGO material. The observable differences between graphene oxide and CCGO originated mainly from the greater surface area in case of CCGO $\left(446 \mathrm{~m}^{2} \mathrm{~g}^{-1}\right)$ in contrast with the pure graphene oxide $\left(342 \mathrm{~m}^{2} \mathrm{~g}^{-1}\right)$, enhancing the availability of effective surfaces for sorption. Thus, the more effective deployment of relevant adsorption sites can be accomplished by the new adsorbent [54].

$\mathrm{pH}$ is an extremely significant variable affecting both the adsorption characteristics and the speciation of chromium. There are several forms of $\mathrm{Cr}(\mathrm{VI})$, namely chromate $\left(\mathrm{CrO}_{4}{ }^{2-}\right)$, dichromate $\left(\mathrm{Cr}_{2} \mathrm{O}_{7}{ }^{2-}\right)$ and hydrogen chromate $\left(\mathrm{HCrO}_{4}^{-}\right)$[46]. These ionic forms are related to the solution $\mathrm{pH}$, as well as to the total chromate concentration. During the adsorption, $\mathrm{Cr}(\mathrm{VI})$ is partially reduced to $\mathrm{Cr}(\mathrm{III})$ by the reductive surface hydroxyl groups, existing on the CCGO surface. According to the obtained results, when increasing the $\mathrm{pH}$ value, the uptake of $\mathrm{Cr}(\mathrm{VI})$ decreases, which is due to the higher concentration of $\mathrm{OH}^{-}$ions present in the solution, competing with the $\mathrm{Cr}(\mathrm{VI})$ species. On this basis, when the $\mathrm{pH}$ is low (i.e., $\mathrm{pH}<4$ ), the uptake of $\mathrm{Cr}(\mathrm{VI})$ is about $55 \mathrm{mg} \mathrm{g}^{-1}$, but at higher $\mathrm{pH}$ levels (i.e., $\mathrm{pH}>6.5$ ), the uptake of $\mathrm{Cr}(\mathrm{VI})$ decreases to $38 \mathrm{mg} \mathrm{g}^{-1}$, when the initial $\mathrm{Cr}(\mathrm{VI})$ concentration is $50 \mathrm{mg} \mathrm{L}^{-1}$ and the dosage of CCGO is $1 \mathrm{~g} \mathrm{~L}^{-1}$. These results show the high potential of CCGO as an example of new composite materials, to remove effectively metal ions from wastewaters $[54,55]$.

A recent study [56] involves the adsorption of hexavalent chromium, using chitosan grafted graphene oxide nanocomposite (CS-GO) in batch mode, providing an adsorption capacity of $104 \mathrm{mg} \mathrm{g}^{-1}$, achieved at $\mathrm{pH} 2.0$ and for the contact time of $420 \mathrm{~min}$, noting also that the CS-GO material is recyclable up to 10 cycles with the minimum loss of adsorption capacity.

\subsection{Application of Poly-Pyrrole Graphene Oxide Nanocomposite (PPy-GO NC) for Cr(VI) Removal}

The sorption of $\mathrm{Cr}(\mathrm{VI})$ onto poly-pyrrole graphene oxide nanocomposite (PPy-GO NC) from waters was examined by Setshedi et al. (2015) [57], using batch and packed-bed column operational modes. The batch sorption isotherm data at the optimal solution $\mathrm{pH}$ value 2 were adequately described by the Langmuir isotherm model with a maximum sorption capacity $625 \mathrm{mg} \mathrm{g}^{-1}$ at $25^{\circ} \mathrm{C}$. The sorption of $\mathrm{Cr}(\mathrm{VI})$ onto the PPy-GO NC adsorbent from binary ions systems was also assessed and the results revealed that the existence of ions had no significant effect on $\mathrm{Cr}(\mathrm{VI})$ removal. In addition, a volume of $\mathrm{Cr}(\mathrm{VI})$ contaminated water $(64 \mathrm{~L})$, with $10 \mathrm{mg} \mathrm{L}^{-1}$, was effectively treated in column experiments, using $2 \mathrm{~g}$ of PPy-GO NC at a flow rate of $3 \mathrm{~mL} \mathrm{~min}^{-1}$, effectively achieving the maximum allowable discharge limit.

\subsection{Application of a Reductive and Magnetic Graphene/Fe ${ }_{3} \mathrm{O}_{4}$ Composite for $\mathrm{Cr}(\mathrm{VI})$ Removal}

A highly reductive and magnetic graphene/ $\mathrm{Fe}_{3} \mathrm{O}_{4}$ composite $\left(\mathrm{HR}-\mathrm{M}-\mathrm{GO} / \mathrm{Fe}_{3} \mathrm{O}_{4}\right.$ ) was created via the graphene oxide (GO) in situ oxidation of $\mathrm{FeCl}_{2}$ by Hou et al. (2016) [58]. This super-paramagnetic composite material could be utilized for the exceedingly efficient removal of $\mathrm{Cr}(\mathrm{VI})$ from wastewaters, appropriately separated by employing an external magnet. The maximum adsorption capacity of the HR-M-GO/ $/ \mathrm{Fe}_{3} \mathrm{O}_{4}$ for $\mathrm{Cr}(\mathrm{VI})$ achieves $32 \mathrm{mg} \mathrm{g}^{-1}$, which is bigger than the simple graphene $/ \gamma-\mathrm{Fe}_{2} \mathrm{O}_{3}$ composite. The probable mechanism of $\mathrm{HR}-\mathrm{M}-\mathrm{GO} / \mathrm{Fe}_{3} \mathrm{O}_{4}$, removing $\mathrm{Cr}(\mathrm{VI})$ efficiently was that $\mathrm{Cr}(\mathrm{VI})$ reduced to $\mathrm{Cr}(\mathrm{III})$ by the occurrence of ferrous hydroxide in the graphene structure and the resulting $\mathrm{Cr}(\mathrm{III})$ ions were simply captured by the negatively charged composite materials ( $\left.\mathrm{HR}-\mathrm{M}-\mathrm{GO} / \mathrm{Fe}_{3} \mathrm{O}_{4}\right)$.

\subsection{Application of Graphene Oxide/Poly-Amido-Amine Dendrimer (GO/PAMAMs) Composites for Cr(VI) Removal}

Graphene oxide/poly-amido-amine dendrimer (GO/PAMAMs) composites [59] were utilized to remove $\mathrm{Cr}(\mathrm{VI})$ from mimicked effluents. The results exhibited that the optimal $\mathrm{pH}$ value was 2.5, the removal percentage reached $91 \%$ for $30 \mathrm{mg} \mathrm{L}^{-1}$ initial concentration of $\mathrm{Cr}(\mathrm{VI})$ within $120 \mathrm{~min}$ 
and the maximum adsorption capacity reached $211 \mathrm{mg} \mathrm{g}^{-1}$ at $40{ }^{\circ} \mathrm{C}$; while in the $\mathrm{pH}$ range of values 2.5-7.0, there was a sharp decline, regarding the removal efficiency of $\mathrm{Cr}(\mathrm{VI})$, i.e., it decreased as the $\mathrm{pH}$ value increased.

Table 3 shows the reviewed nanomaterials applied for $\mathrm{Cr}(\mathrm{VI})$ removal from water sources, providing information about their major structural characteristics and applications in water treatment. A comparison between the sorption capacities of selected adsorbents, recently reported in literature for the removal of $\mathrm{Cr}(\mathrm{VI})$ from aqueous solutions, is presented in Table 4, indicating that the previously presented nanomaterials (i.e., $\mathrm{NiO}$ and CCGO) showed enhanced sorption capacities (Table 3).

Table 3. Novel nanostructured materials applied for the removal of chromium mainly from wastewater sources.

\begin{tabular}{|c|c|c|c|c|c|c|}
\hline $\begin{array}{c}\text { Novel } \\
\text { Nano-Material }\end{array}$ & $\mathrm{NiO}$ & CCGO & CS-GO & PPy-GO NC & $\mathrm{HR}-\mathrm{M}-\mathrm{GO} / \mathrm{Fe}_{3} \mathrm{O}_{4}$ & GO/PAMAMs \\
\hline $\begin{array}{c}\text { Cr species } \\
\text { removal }\end{array}$ & $\mathrm{Cr}(\mathrm{VI})$ & $\mathrm{Cr}(\mathrm{VI})$ & $\mathrm{Cr}(\mathrm{VI})$ & $\mathrm{Cr}(\mathrm{VI})$ & $\mathrm{Cr}(\mathrm{VI})$ & $\mathrm{Cr}(\mathrm{VI})$ \\
\hline Dose $\left(\mathrm{g} \mathrm{L}^{-1}\right)$ & 0.6 & 1 & 2 & 2 & 0.5 & 0.5 \\
\hline $\begin{array}{l}\text { C initial } \\
\left(\mathrm{mg} \mathrm{L}^{-1}\right)\end{array}$ & 20 & 50 & 50 & 10 & 10 & 50 \\
\hline $\mathrm{pH}$ & 4.7 & 3.0 & 2.0 & 2.0 & 3.0 & 2.5 \\
\hline $\begin{array}{l}\text { Adsorption } \\
\text { capacity } \\
\left(\mathrm{mg} \mathrm{g}^{-1}\right)\end{array}$ & 5 & 68 & 104 & 625 & 32 & 211 \\
\hline References & $\begin{array}{l}\text { Behnajady and } \\
\text { Bimeghdar } \\
\text { (2014) [53] }\end{array}$ & $\begin{array}{c}\text { Li et al. } \\
(2013) \\
{[54]}\end{array}$ & $\begin{array}{l}\text { Samuel et al. } \\
(2019) \text { [56] }\end{array}$ & $\begin{array}{l}\text { Setshedi et al. } \\
\text { (2015) [57] }\end{array}$ & $\begin{array}{c}\text { Hou et al. (2016) } \\
\text { [58] }\end{array}$ & $\begin{array}{l}\text { Liu et al. } \\
\text { (2019) [59] }\end{array}$ \\
\hline
\end{tabular}

Table 4. Comparison of the sorption capacities of various sorbents towards $\mathrm{Cr}(\mathrm{VI})$ ions.

\begin{tabular}{ccc}
\hline \multirow{2}{*}{ Sorbent Material } & Sorption Capacity $\left(\mathbf{m g ~ g}^{-\mathbf{1}}\right)$ & Reference \\
\cline { 2 - 2 } & Cr (VI) & \\
\hline Amino starch & 12 & Dong et al. (2010) [60] \\
Silica matrices & 18 & Alvarez et al. (2011) [61] \\
Mesoporous TiO & 33 & Asuha et al. (2010) [62] \\
Alumina & 4 & Rajiv Gandhi et al. (2010) [63] \\
Alumina/chitosan composite & 9 & Rajiv Gandhi et al. (2010) [63] \\
Activated Alumina & 2 & Bishnoi et al. (2004) [64] \\
\hline
\end{tabular}

Table 3 displays comparative results obtained from the different materials presented in this paper. Regarding $\mathrm{Cr}(\mathrm{VI})$ adsorption, it was shown that the most efficient adsorption takes place at $\mathrm{pH}$ values between 2 and 5 (i.e., acidic conditions) for almost all reviewed materials. Poly-pyrrole graphene oxide nanocomposite (PPy-GO NC) presents maximum sorption capacity $625 \mathrm{mg} \mathrm{g}^{-1}$ at $25^{\circ} \mathrm{C}$. Higher adsorption capacity was observed by graphene based materials, compared especially to nickel oxide nanoparticles $(\mathrm{NiO})$, which contain no graphene in its structure and provide the relatively lower absorption capacity $\left(5 \mathrm{mg} \mathrm{g}^{-1}\right)$. The low (acidic) $\mathrm{pH}$ values is the main reason why adsorption is not considered as a favorable method for the removal of $\mathrm{Cr}(\mathrm{VI})$ at $\mathrm{pH}$ values more relevant to drinking water sources (i.e., 6.5-8.5). However, these adsorbents could be useful for the treatment of acidic wastewaters.

\section{Nanostructured Materials for Uranium Removal}

\subsection{Uranium (U)}

Identified as a harmful element, uranium (U) is plentiful in nuclear waste disposal facilities (and testing sites), as well as in uranium mining, processing and milling sites. In groundwaters, 
it is usually present in the form of $\mathrm{U}(\mathrm{VI})$. Uranium contamination poses a threat to both surface and groundwaters $[65,66]$. Uranium disposed into the environment can ultimately reach the top of food chain and be consumed by humans, initiating severe kidney or liver damage and even death [67]. Thus, the WHO and US EPA recognized $\mathrm{U}(\mathrm{VI})$ as a human carcinogen and recommended $30 \mu \mathrm{g} \mathrm{L}^{-1}$ as the temporary guideline level for its presence in drinking water, after the 2012 relevant revision [68]. The contamination of groundwaters with uranium is a subject of concern in several countries around the world, such as in the USA, Canada, Germany, Finland, Norway, and Greece [68]. Therefore, it is very important to choose a suitable and effective method to remove uranium from water sources.

$\mathrm{U}(\mathrm{VI})$ is the most ubiquitous species of uranium in aerated waters, whereas in anoxic groundwaters, uranium is usually absent, because the respective reduced form (U(IV)) is insoluble in water [69]. The major uranium species in water supplies are the anionic carbonate complexes, i.e., the $\mathrm{UO}_{2}\left(\mathrm{CO}_{3}\right)_{2}^{2-}$ at $\mathrm{pH}$ values lower than 7 and the $\mathrm{UO}_{2}\left(\mathrm{CO}_{3}\right)_{3}^{4-}$ at $\mathrm{pH}$ greater than 8 , whereas at $\mathrm{pH}$ values between 5 and 6.5 the neutral $\mathrm{UO}_{2} \mathrm{CO}_{3}$ species may also make up an important part, which depending on $\mathrm{pH}$, could vary between $20 \%-90 \%$ [69].

The creation of the aforementioned complexes with carbonates determines its removal from water, depending on the application of specific treatment processes. For example, conventional methods, such as coagulation or lime softening, can remove uranium from water, but they are very sensitive to $\mathrm{pH}$ changes and water composition [8]. On the contrary, ion-exchange [70,71] is the most efficient removal method, because it can remove about $98 \%$ of uranium from water, mainly through the removal of anionic uranium carbonate species; the ion exchange resins used in this case are usually selective strong base (anionic) [8]. Membrane treatment methods, such as nano-filtration [72] or reverse osmosis, were also found to be efficient for the removal of uranium, removing the respective carbonate complexes by more than $90 \%$, but their application requires experienced personnel and their use is quite expensive, especially when designed for the treatment of small volumes of contaminated water $[8,73,74]$.

\subsection{Application of $\mathrm{Fe}_{3} \mathrm{O}_{4} @ \mathrm{SiO}_{2}$ Composite Nanoparticles for U(VI) Removal}

Das et al. (2010) [75] studied the sorption of U(VI) on magnetite $\left(\mathrm{Fe}_{3} \mathrm{O}_{4}\right)$ nanoparticles, but the sorption capacity was relatively small. Silica has been known as one of the most ideal coating layers for the magnetic $\mathrm{Fe}_{3} \mathrm{O}_{4}$ nanoparticles, due to its reliable chemical stability, biocompatibility, and facile surface modification. Magnetic $\mathrm{Fe}_{3} \mathrm{O}_{4} @ \mathrm{SiO}_{2}$ composite particles were successfully applied by Fan et al. (2012) [66] as a novel and effective adsorbent material for the removal of U(VI) from aqueous solutions. The sorption of $\mathrm{U}(\mathrm{VI})$ onto magnetic $\mathrm{Fe}_{3} \mathrm{O}_{4} @ \mathrm{SiO}_{2}$ composite particles was strongly dependent on $\mathrm{pH}$ values. With increasing $\mathrm{pH}$ (i.e., from 2 to 6 ), the adsorption capacity was also increased. When the initial $\mathrm{pH}$ value varied from 2 to 4 , the sorption capacity of $\mathrm{U}(\mathrm{VI})$ increased from 0 to $8.5 \mathrm{mg} \mathrm{g}^{-1}$, while when the initial $\mathrm{pH}$ was further increased from 4 to 6 , the sorption capacity of uranium increased substantially (i.e., from 8 to $20 \mathrm{mg} \mathrm{g}^{-1}$ ). However, when increasing the $\mathrm{pH}$ value from 6 to 8 , the sorption capacity started to decrease. The maximum sorption value for $\mathrm{U}(\mathrm{VI})$ onto $\mathrm{Fe}_{3} \mathrm{O}_{4} @ \mathrm{SiO}_{2}$ magnetic composites was about $20 \mathrm{mg} \mathrm{g}^{-1}$, when the initial concentration of $\mathrm{U}$ was $50 \mathrm{mg} \mathrm{L}^{-1}$. Therefore, the optimum (initial) $\mathrm{pH}$ value was 6, when applying this treatment technique, which is in agreement with other relevant studies regarding the sorption of $\mathrm{U}(\mathrm{VI})$ onto iron oxides or hydroxides, i.e., they present a maximum sorption capacity in the $\mathrm{pH}$ range between 6-7 [76-78].

The aforementioned magnetic $\mathrm{Fe}_{3} \mathrm{O}_{4} @ \mathrm{SiO}_{2}$ composite particles showed an excellent ability to remove uranium from aqueous solutions and the maximum $\mathrm{U}(\mathrm{VI})$ sorption capacity was about $52 \mathrm{mg} \mathrm{g}^{-1}$ at $25^{\circ} \mathrm{C}$. Hence, this adsorbent material could be a potential candidate to remove the toxic $\mathrm{U}(\mathrm{VI})$ forms from aqueous solutions and the results of this study can also provide a technique for the removal or recovery of other heavy/toxic metal ions from aqueous solution [66].

\subsection{Application of a Novel Graphene Oxide-Activated Carbon Felt Composite for U(VI) Removal}

Chen et al. (2013) [67], prepared a composite material, Graphene oxide (GO)-activated carbon felt $(\mathrm{ACF})(\mathrm{GO}-\mathrm{ACF})$ and tested for the removal of $\mathrm{U}(\mathrm{VI})$ from aqueous solution, comparing the simple 
ACF and the composite GO-ACF materials. The adsorption of $\mathrm{U}(\mathrm{VI})$ on ACF is remarkably improved by the presence of GO, covalently bonding with ACF. The maximum sorption capacity of GO-ACF for $\mathrm{U}(\mathrm{VI})$ was evaluated to be $298 \mathrm{mg} \mathrm{g}^{-1}$ at $\mathrm{pH}$ 5.5, i.e., much higher than that of ACF $\left(173 \mathrm{mg} \mathrm{g}^{-1}\right)$, suggesting that the carboxyl functional groups of GO-ACF can play an important role in the sorption.

\subsection{Application of a Three-Dimensional Layered Double Hydroxide-Graphene Hybrid Material for $U(V I)$ Removal}

Graphene has recently attracted attention for its $\mathrm{U}(\mathrm{VI})$ sorption and recent studies have reported a substantially high maximum sorption capacity of $299 \mathrm{mg} \mathrm{g}^{-1}$ at the $\mathrm{pH}$ value 4 [79], mainly due to the formation of inner-sphere surface complexes of U(VI) on GO. In the past few years, the layered double hydroxides (LDHs) containing transition metals, have also been employed as effective adsorption materials. Their large interlayer space and the high concentration of active sites have allowed the preparation of several multi-functional LDH materials to be used as anion exchangers, adsorbents, or magnetic materials. Tan et al. (2015) [80] synthesized a 3-D hierarchical composite with graphene sandwiched between two layers of NiAl-LDH nanosheets, by using a simple and cost effective in situ growth procedure; during the in situ crystallization process NiAl-LDH nanosheets grew on the surface of GO@AlOOH sheets, obtained by mixing boehmite $\mathrm{AlOOH}$ primer sol with GO solution, under specific conditions [80].

When examined as an adsorbent for U(VI) removal, several advantages of this NiAl-LDH composite material make it specifically attractive, because: (1) it is manufactured using an easy, non-toxic synthesis procedure; (2) the larger specific surface area of $257 \mathrm{~m}^{2} \mathrm{~g}^{-1}$ can provide more adsorptive sites; (3) it can be used for the effective adsorption/removal of uranium(VI) ions.

The adsorption of $\mathrm{U}(\mathrm{VI})$ onto $\mathrm{rGO} / \mathrm{LDH}$ was carried out by varying the $\mathrm{pH}$ values (2-12); it was found that the adsorption capacity was highly dependent on $\mathrm{pH}$ value. At $\mathrm{pH}$ less than $4, \mathrm{U}(\mathrm{VI})$ is present in solution predominantly in the form of $\mathrm{UO}_{2}{ }^{2+}$ with a lower sorption capacity, mainly due to the competition of $\mathrm{H}^{+}$ions for the binding sites of adsorbent. At the $\mathrm{pH}$ range 4-8, the hydrolysis of uranyl ions occurs, producing several uranium species that include $\mathrm{UO}_{2}(\mathrm{OH})^{+},\left(\mathrm{UO}_{2}\right)(\mathrm{OH})_{2}$, $\left(\mathrm{UO}_{2}\right)_{3}(\mathrm{OH})_{5}{ }^{+}$and $\left(\mathrm{UO}_{2}\right)_{2}(\mathrm{OH})_{2}{ }^{2+}$, which are available for adsorption onto $\mathrm{rGO} / \mathrm{LDH}$, and the sorption reaches a maximum value, especially in the absence of carbonates. In $\mathrm{pH}$ values $>8$, the fraction of $\left(\mathrm{UO}_{2}\right)_{3}(\mathrm{OH})_{7}{ }^{-}$anions (known for their generally low sorption affinity) increases, leading to a decrease of uranium(VI) uptake. As a consequence, the $\mathrm{pH}$ value 4 is considered optimum for the adsorption of $\mathrm{U}(\mathrm{VI})$ onto $\mathrm{rGO} / \mathrm{LDH}$ with maximum sorption capacity of the $\mathrm{rGO} / \mathrm{LDH}$ composite for uranium (VI) $278 \mathrm{mg} \mathrm{g}^{-1}$. Therefore, $\mathrm{rGO} / \mathrm{LDH}$ is a novel adsorbent, exhibiting a bright future for practical application, regarding the removal of $\mathrm{U}(\mathrm{VI})$ from aqueous solutions [80].

\subsection{Application of Graphene Oxide and Its Amine-Functionalized Composite (GO-NH $\left.\mathrm{H}_{2}\right)$ for U(VI) Removal}

A new amine-functionalized graphene oxide $\left(\mathrm{GO}-\mathrm{NH}_{2}\right)$ nanosheet was prepared via covalently grafting reaction by Liu et al. (2016) [81]. The adsorption capacities of $\mathrm{GO}$ and of $\mathrm{GO}-\mathrm{NH}_{2}$ were found to be 97 and $215 \mathrm{mg} \mathrm{g}^{-1}$ at $298 \mathrm{~K}$, respectively. These results showed that the adsorption capacity of $\mathrm{GO}$ was significantly improved by amine functionalization. The adsorption of $\mathrm{UO}_{2}{ }^{2+}$ ions depends upon the uranium species distribution in solution, which mostly depends on the respective $\mathrm{pH}$ value. Uranium can be hydrolyzed into different mononuclear and polynuclear hydrolysis products in the form of $\left.\left(\mathrm{UO}_{2}\right)_{\mathrm{m}}(\mathrm{OH})_{\mathrm{n}}\right]^{(2 \mathrm{~m}-\mathrm{n})+}[82]$. As the $\mathrm{pH}$ value is lower than 4 , the $\mathrm{UO}_{2}{ }^{2+}$ ions exist predominantly in the aqueous solution as the monomeric species. However, with the increase of $\mathrm{pH}$, the hydrolysis of $\mathrm{U}(\mathrm{VI})$ ions will occur. Both materials achieved their maximum sorption capacity at the $\mathrm{pH}$ value 5.5.

\subsection{Application of a Novel Graphene Oxide-Immobilized Saccharomyces Cerevisiae Gel Beads for $U(V I)$ Removal}

According to a recent study by Chen and Wang (2016) [83], the waste biomass of Saccharomyces cerevisiae was immobilized using several agents, including Ca-alginate (Ca-SA), Ca-alginate plus 
graphene oxide (Ca-SA-GO), or in combination with polyvinyl alcohol (PVA, $5 \%$ or $10 \%, w / v)$, i.e., PVA-Ca-SA-GO, using a $\mathrm{CaCl}_{2}$-boric acid solution, in order to evaluate their ability to adsorb dissolved $\mathrm{U}(\mathrm{VI})$. The obtained experimental results showed that graphene oxide at $0.01 \%(w / v)$ could enhance the performance of immobilized cells.

The yeast gel beads, prepared with 5\% PVA, $1 \% \mathrm{SA}, 2 \%$ yeast, $0.01 \% \mathrm{GO}, 2 \% \mathrm{CaCl}_{2}$ and saturated boric acid, generally showed better physical-chemical properties, such as higher tolerance, when unfavorable environmental conditions were applied. Moreover, the gel beads exhibited more stable capacity for $\mathrm{U}(\mathrm{VI})$ sorption and desorption at various conditions, such as $\mathrm{pH}$ in the range of 3-9. The effects of initial $\mathrm{pH}$ at acidic $(\mathrm{pH}=3)$, neutral $(\mathrm{pH}=7)$ and alkaline conditions $(\mathrm{pH}=9)$ on $\mathrm{U}(\mathrm{VI})$ adsorption were studied and the results suggested that the optimum $\mathrm{pH}$ value for $\mathrm{U}(\mathrm{VI})$ adsorption is between 2.6 and 5. The immobilized Saccharomyces cerevisiae biomass, using SA, PVA and/or GO substrate materials, showed particular changes in the molecular vibration of functional groups, such as carboxyl, amide and hydroxyl groups, which may be involved in the U(VI) binding, when compared with the raw yeast biomass.

\subsection{Application of Carboxyl-Functionalized Graphene Oxide (COOH-GO) Material for U(VI) Removal}

The effect of increasing the presence of specific chemical functional groups, such as the carboxyl groups, on the selectivity of uranium sorption was investigated by using a carboxyl-functionalized graphene oxide (COOH-GO) modified material, which was studied in comparison with the simple graphene oxide (GO) and with graphite [84]. According to Mohamud et al. (2018), the modified $\mathrm{COOH}-\mathrm{GO}$ demonstrated superior performance as a sorbent material for the selective removal of uranyl ions from aqueous solution with distribution coefficient value, $K, 3.72 \pm 0.19 \times 10^{3} \mathrm{~mL} \mathrm{~g}^{-1}$ in comparison to $3.97 \pm 0.5 \times 10^{2}$ and $2.68 \pm 0.2 \times 10^{2} \mathrm{~mL} \mathrm{~g}^{-1}$ values for $\mathrm{GO}$ and graphite, respectively. Moreover, COOH-GO presents a higher sorption capacity for $\mathrm{U}\left(Q_{\max }=169 \mathrm{mg} \mathrm{g}^{-1}\right)$ and shows a greater selectivity towards $U$ with $65.9 \pm 2.7 \%$ retained in the presence of competing ions in comparison to $38.9 \pm 1.2 \%$ value, observed for $\mathrm{GO}$, at the optimum $\mathrm{pH}$ 4. These enhanced values are most probable due to the effect of selective surface groups presence, such as the carboxyl.

\subsection{Application of a Composite Material (GO-DTPAA) for U(VI) Removal}

A novel chelator diethyl-enetri-amine-penta-acetic phenyl-enedi-amine (DTPAA) was covalently bonded to a supporting matrix of graphene oxide (GO), and a composite material (GO-DTPAA) was obtained recently by Liu et al. (2018) [85]. The obtained results indicated that GO-DTPAA was a highly efficient absorbent for the removal of $\mathrm{U}(\mathrm{VI})$ from aqueous solutions at $\mathrm{pH}$ 6.5. The adsorption capacity of GO-DTPAA was as high as $485 \mathrm{mg} \mathrm{g}^{-1}$ at $298 \mathrm{~K}$, which was far greater than that of pristine GO $\left(97 \mathrm{mg} \mathrm{g}^{-1}\right)$ at the same temperature. The thermodynamic parameters revealed that the adsorption of uranium ions onto the pristine GO and by the GO-DTPAA composite material are feasible, spontaneous and endothermic.

\subsection{Application of a Magnetic Reduced-Graphene Oxide/Tea Waste Composite for U(VI) Removal}

Recently, Yang et al. (2019) [86] studied the preparation and application of relatively low-cost and highly efficient adsorptive materials for the removal of uranium from nuclear wastes, such as composites of graphene oxide (GO) and tea waste (TW). The composites GO-TW and the magnetic $\mathrm{rGO} / \mathrm{Fe}_{3} \mathrm{O}_{4} / \mathrm{TW}$ exhibited higher adsorption capacities and faster adsorption kinetics than the simple materials GO and TW $\left(Q_{\max (\mathrm{TW})}=92 \mathrm{mg} \mathrm{g}^{-1}, Q_{\max (\mathrm{GOTW})}=112 \mathrm{mg} \mathrm{g}^{-1}\right.$ and $\left.Q_{\max (\mathrm{rGO} / \mathrm{Fe} 3 \mathrm{O} 4 / \mathrm{TW})}=105 \mathrm{mg} \mathrm{g}^{-1}\right)$, resulting to higher removal rates $(\sim 99 \%)$ for $\mathrm{U}(\mathrm{VI})$. As aforementioned, the solution $\mathrm{pH}$ substantially affects the speciation of uranium in the aqueous solutions, and hence, significantly influences the uranium adsorption process. The adsorption of $\mathrm{U}(\mathrm{VI})$ on $\mathrm{TW}$, GOTW and $\mathrm{rGO} / \mathrm{Fe}_{3} \mathrm{O}_{4} / \mathrm{TW}$ significantly increased with increasing the $\mathrm{pH}$ value from 2.0 to 5.0. At the $\mathrm{pH} 5$, the removal rate of uranium by TW, GOTW and $\mathrm{rGO} / \mathrm{Fe}_{3} \mathrm{O}_{4} / \mathrm{TW}$ materials reached the highest values, noting that at $\mathrm{pH}$ value $<4.0$, uranium exists mainly in the form of $\mathrm{UO}_{2}{ }^{2+}$. Furthermore, due to the advantageous magnetic 
properties, $\mathrm{rGO} / \mathrm{Fe}_{3} \mathrm{O}_{4} / \mathrm{TW}$ can be easily separated from the treated aqueous solutions, thus enhancing the post-treatment efficiency for further practical applications.

Table 5 shows the reviewed nanomaterials applied for U(VI) removal from waste/water sources, providing major information about their structural characteristics and their applications in water treatment.

Table 5. Novel nanostructured materials applied for the removal of $\mathrm{U}(\mathrm{VI})$ from waste/water sources.

\begin{tabular}{|c|c|c|c|c|c|c|c|c|c|}
\hline $\begin{array}{c}\text { Novel } \\
\text { Nano-Material }\end{array}$ & $\mathrm{Fe}_{3} \mathrm{O}_{4} @ \mathrm{SiO}_{2}$ & GO & GO-ACF & $\begin{array}{c}\text { rGO/ } \\
\text { NiAl-LDH }\end{array}$ & GO-NH ${ }_{2}$ & SA-GO & COOH-GO & GO-DTPAA & $\begin{array}{c}\mathrm{rGO} / \mathrm{Fe}_{3} \mathrm{O}_{4} / \\
\text { TW }\end{array}$ \\
\hline Dose $\left(\mathrm{g} \mathrm{L}^{-1}\right)$ & 2.5 & 0.4 & 0.2 & 0.5 & 0.2 & 0.1 & 1.0 & 0.1 & 0.5 \\
\hline $\begin{array}{l}\mathrm{C} \text { initial } \\
\left(\mathrm{mg} \mathrm{L}^{-1}\right)\end{array}$ & 50 & 119 & 50 & 130 & 60 & 35.6 & 10 & 50 & 10 \\
\hline $\mathrm{pH}$ & 6.0 & 4.0 & 5.5 & 4.0 & 5.5 & 5.0 & 4.0 & 6.5 & 5.0 \\
\hline $\begin{array}{l}\text { Adsorption } \\
\text { capacity } \\
\left(\mathrm{mg} \mathrm{g}^{-1}\right)\end{array}$ & 52 & 299 & 298 & 278 & 215 & 162 & 169 & 485 & 105 \\
\hline References & $\begin{array}{c}\text { Fan et al. } \\
(2012) \\
{[66]}\end{array}$ & $\begin{array}{c}\text { Li et al. } \\
(2012) \\
{[79]}\end{array}$ & $\begin{array}{c}\text { Chen et al. } \\
\text { (2013) } \\
{[67]}\end{array}$ & $\begin{array}{c}\text { Tan et al. } \\
\text { (2015) } \\
{[80]}\end{array}$ & $\begin{array}{l}\text { Liu et al. } \\
\text { (2016) } \\
\text { [81] }\end{array}$ & $\begin{array}{l}\text { Chen and } \\
\text { Wang } \\
\text { (2016) [83] }\end{array}$ & $\begin{array}{c}\text { Mohamud } \\
\text { et al. } \\
\text { (2018) [84] }\end{array}$ & $\begin{array}{c}\text { Liu et al. } \\
\text { (2018) } \\
{[85]}\end{array}$ & $\begin{array}{c}\text { Yang et al. } \\
\text { (2019) } \\
{[86]}\end{array}$ \\
\hline
\end{tabular}

As revealed from Table 5, the proposed materials seem to work more efficiently for the U(VI) removal at $\mathrm{pH}$ values between $4-6$. The composite material (GO-DTPAA) exhibits maximum absorption capacity $485 \mathrm{mg} \mathrm{g}^{-1}$. The other proposed materials with graphene, showed an average high adsorption capacity of $200-300 \mathrm{mg} \mathrm{g}^{-1}$.

Table 6 provides the comparison of sorption capacity between different adsorbents, when applied for the removal of uranium. As can be observed by comparing the relevant data of Tables 5 and 6 , the sorption ability of the previously described nanostructured materials was generally substantially higher.

Table 6. Comparison of sorption capacities between various sorbents towards the removal of U(VI) ions.

\begin{tabular}{|c|c|c|c|}
\hline \multirow{2}{*}{ Sorbent Material } & \multirow{2}{*}{$\mathrm{pH}$} & Sorption Capacity $\left(\mathrm{mg} \mathrm{g}^{-1}\right)$ & \multirow{2}{*}{ Reference } \\
\hline & & $\mathrm{Cr}(\mathrm{VI})$ & \\
\hline Manganese oxide coated zeolite & 4.0 & 15 & Han et al. (2007) [87] \\
\hline Natural sepiolite & 3.0 & 35 & Donat (2009) [88] \\
\hline Modified clays with titanium oxide & 3.5 & 0.6 & Humelnicu et al. (2009) [89] \\
\hline Magnetite nanoparticles & 7.0 & 5 & Das et al. (2010) [75] \\
\hline Ethylenediamine-modified chitosan & 3.0 & 83 & Wang et al. (2011) [90] \\
\hline Goethite $(\alpha-\mathrm{FeOOH})$ & 6.0 & 34 & Yusan et al. (2011) [91] \\
\hline $\begin{array}{l}\text { Binary iron-manganese } \\
\text { oxy-hydroxides (FMHO) }\end{array}$ & 6.5 & 133 & Dimiropoulos et al. (2015) [92] \\
\hline
\end{tabular}

\section{Conclusions}

The pollution of natural waters caused by toxic metals is a global issue, and various treatment technologies have been developed to remove these inorganic pollutants from water sources (mostly from groundwater). The application of most important novel nanostructured materials was summarized, regarding the removal of arsenic ( $\mathrm{As}(\mathrm{III})$ and $\mathrm{As}(\mathrm{V}))$, chromium $((\mathrm{Cr}(\mathrm{III})$ and $\mathrm{Cr}(\mathrm{VI}))$ and uranium $(\mathrm{U}(\mathrm{VI}))$ from aqueous systems. As it was shown, the use of nanostructured materials, exhibiting generally higher surface areas and average structural sizes below $100 \mathrm{~nm}$, could be very promising in this direction.

Specifically, in this review, the most certain of the novel and recently applied materials for the removal of certain inorganic pollutants from water sources were summarized, providing their major structure characteristics and application conditions (Table 1), according to relevant recent literature. In particular, the removal of arsenic was examined by the application of hierarchically porous $\mathrm{CeO}_{2}-\mathrm{ZrO}_{2}$ nanospheres material, as well as by the incorporation of other metal ions into 
the lattice structure of iron(III) oxide, such as the hydrous titanium(IV), the bimetallic mixed oxide (NHITO), and the copper(II) binary oxide nanomaterials.

Of particular interest was the application of graphene and a series of novel composite materials based on graphene oxide ( $\mathrm{GO})$, such as graphene oxide-ferric hydroxide $\mathrm{GO} / \mathrm{Fe}(\mathrm{OH})_{3}$ composites, magnetite $\mathrm{Fe}_{3} \mathrm{O}_{4}$-reduced graphite oxide- $\mathrm{MnO}_{2}$ and graphene oxide-hydrated zirconium oxide. Among these materials, the iron(III)-copper(II) binary oxide and the $\mathrm{Fe}_{3} \mathrm{O}_{4}$-reduced graphite oxide- $\mathrm{MnO}_{2}$, showed particularly high adsorption capacity for the case of As(III) in comparison to As(V), especially for the treatment of anaerobic groundwaters, mostly containing As(III), and avoiding the preliminary oxidation step to the pentavalent As form.

Regarding chromium removal, this review referred to the application of nickel oxide nanoparticles, because of their high surface area, and their very promising magnetic cyclodextrin-chitosan/graphene oxide (CCGO) and other composite materials, such as CS-GO, PPy-GO NC, HR-M-GO/ $\mathrm{Fe}_{3} \mathrm{O}_{4}$, GO/PAMAMs. These materials, were found to be very efficient for the adsorption/removal of $\mathrm{Cr}(\mathrm{VI})$, but only in the strongly acidic $\mathrm{pH}$ area, i.e., at $\mathrm{pH}$ values below 5, and therefore, they could find applications for the treatment of acidic wastewaters, avoiding the usually applied preliminary reduction step towards the $\mathrm{Cr}$ (III) formation.

Uranium could likely be removed from aqueous solutions by the application of magnetic $\mathrm{Fe}_{3} \mathrm{O}_{4} @ \mathrm{SiO}_{2}$ composite particles, as a novel and effective adsorbent material, as well as by the application of several novel and optimum graphene modified composite materials, such as rGO/LDH, GO-ACF, GO-NH $\mathrm{N}_{2}, \mathrm{COOH}-\mathrm{GO}, \mathrm{GO}-\mathrm{DTPAA}, \mathrm{GO}-\mathrm{TW}$, and $\mathrm{rGO} / \mathrm{Fe}_{3} \mathrm{O}_{4} / \mathrm{TW}$, showing promising results. However, these materials need to be tested for the treatment of much lower initial concentrations, relevant to drinking water treatment. Furthermore, these materials need to be applied in real natural ground/waters, containing all the commonly found co-existing anions, such as carbonate, phosphates and sulfates, because most of the presented results were obtained using deionized waters (i.e., performing model experiments).

Author Contributions: Data curation, A.K.T.; Writing draft, A.K.T. and I.A.K.; Validation, A.I.Z. and I.A.K.; Visualization, A.K.T., I.A.K. and A.I.Z.; Writing-Review and editing, A.K.T., I.A.K. and A.I.Z.; Supervision, A.I.Z. All authors have read and agreed to the published version of the manuscript.

Funding: This research received no external funding.

Conflicts of Interest: The authors confirm that this article content has no conflict of interest.

\section{References}

1. Hashim, M.A.; Mukhopadhyay, S.; Sahu, J.N.; Sengupta, B. Remediation technologies for heavy metal contaminated groundwater. J. Environ. Manag. 2011, 92, 2355-2388. [CrossRef] [PubMed]

2. Siegel, R.W. Nanostructured materials -mind over matter. Nanostruct. Mater. 1993, 3, 1-18. [CrossRef]

3. Zhang, L.; Fang, M. Nanomaterials in pollution trace detection and environmental improvement. Nano Today 2010, 5, 128-142. [CrossRef]

4. Danô, M.; Viglašová, E.; Galamboŝ, M.; Rajec, P.; Novák, I. Sorption behaviour of pertechnetate on oxidized and reduced surface of activated carbon. J. Radioanal. Nucl. Chem. 2017, 314, 2219-2227. [CrossRef]

5. Viglašová, E.; Galamboš, M.; Danková, Z.; Krivosudský, L.; Lengauer, C.L.; Hood-Nowotny, R.; Soja, G.; Rompel, A.; Matík, M.; Briančin, J. Production, characterization and adsorption studies of bamboo-based biochar/montmorillonite composite for nitrate removal. Waste Manag. 2018, 79, 385-394. [CrossRef]

6. Katsoyiannis, I.A.; Zouboulis, A.I. Comparative evaluation of conventional and alternative methods for the removal of arsenic from contaminated groundwaters. Rev. Environ. Health 2006, 21, 25-41. [CrossRef]

7. Katsoyiannis, I.A.; Gachet, C.; von Gunten, U. Fate of $\mathrm{Cr}$ (III) during Ozonation of Secondary Municipal Wastewater Effluent. Ozone Sci. Eng. 2018, 40, 441-447. [CrossRef]

8. Katsoyiannis, I.A.; Zouboulis, A.I. Removal of uranium from contaminated drinking water: A mini review of available treatment methods. Desalin. Water Treat. 2013, 51, 2915-2925. [CrossRef] 
9. Katsoyiannis, I.A.; Xanthopoulou, M.; Zouboulis, A.I. Cr (VI) Femoval from Ground Waters by Ferrous Iron Redox-Assisted Coagulation in a Continuous Treatment Unit Comprising a Plug Flow Pipe Reactor and Downflow Sand Filtration. Appl. Sci. 2020, 10, 802. [CrossRef]

10. Smedley, P.L.; Kinniburgh, D.G. A review of the source, behaviour and distribution of arsenic in natural waters. Appl. Geochem. 2002, 17, 517-568. [CrossRef]

11. Katsoyiannis, I.A.; Mitrakas, M.; Zouboulis, A.I. Arsenic occurrence in Europe: Emphasis in Greece and description of the applied full-scale treatment plants. Desalin. Water Treat. 2015, 54, 2100-2107. [CrossRef]

12. World Health Organization. Preventing Disease through Healthy Environments; WHO: Geneva, Switzerland, 2010.

13. U.S. Environmental Protection Agency. Arsenic Compounds; EPA: Washington, DC, USA, 2012.

14. Appelo, T.; International Association of Hydrogeologists; Netherlands National Committee. Arsenic in Groundwater: A World Problem. In Proceedings of the Symposium Organized by IAH's Dutch Chapter and the Netherlands' Hydrological Society, Utrecht, The Netherlands, 29 November 2006.

15. Bissen, M.; Frimmel, F.H. Arsenic-A Review. Part I: Occurrence, Toxicity, Speciation, Mobility. Acta Hydroch. Hydrob. 2003, 31, 9-18. [CrossRef]

16. Katsoyiannis, I.A.; Voegelin, A.; Zouboulis, A.I.; Hug, S.J. Enhanced As (III) oxidation and removal by combined use of zero valent iron and hydrogen peroxide in aerated waters at neutral pH values. J. Hazard. Mater. 2015, 297, 1-7. [CrossRef] [PubMed]

17. Cullen, W.R.; Reimer, K.J. Arsenic speciation in the environment. Chem. Rev. 1989, 89, 713-764. [CrossRef]

18. Katsoyiannis, I.; Tzollas, N.; Tolkou, A.; Mitrakas, M.; Ernst, M.; Zouboulis, A. Use of novel composite coagulants for arsenic removal from waters-experimental insight for the application of polyferric sulfate (PFS). Sustainability 2017, 9, 590. [CrossRef]

19. Hering, J.; Chen, P.; Wilkie, J.; Elimelech, M. Arsenic Removal from Drinking Water during Coagulation. J. Environ. Eng. 1997, 123, 800-807. [CrossRef]

20. Gupta, K.; Ghosh, U.C. Arsenic removal using hydrous nanostructure iron(III)-titanium(IV) binary mixed oxide from aqueous solution. J. Hazard. Mater. 2008, 161, 884-892. [CrossRef]

21. Zhou, W.; Pan, K.; Tian, C.; Qu, Y.; Lu, P.; Sun, C.C. Mesoporous $\mathrm{TiO}_{2} / \mathrm{r}-\mathrm{Fe}_{2} \mathrm{O}_{3}$ : Bifunctional composites for effective elimination of arsenite contamination through simultaneous photocatalytic oxidation and adsorption. J. Phys. Chem. 2008, 112, 19584-19589. [CrossRef]

22. Arcy, M.D.; Bluck, M.; Vilar, R. Adsorption kinetics, capacity and mechanism of arsenate and phosphate on a bifunctional $\mathrm{TiO}_{2}-\mathrm{Fe}_{2} \mathrm{O}_{3}$ bi-composite. J. Colloid Interface Sci. 2011, 364, $205-212$.

23. Martinson, C.A.; Reddy, K.J. Adsorption of arsenic (III) and arsenic (V) by cupric oxide nanoparticles. J. Colloid Interface Sci. 2009, 336, 406-411. [CrossRef]

24. Zhang, G.; Ren, Z.; Zhang, X.; Chen, J. Nanostructured iron (III)-copper (II) binary oxide: A novel adsorbent for enhanced arsenic removal from aqueous solutions. Water Res. 2013, 47, 4022-4031. [CrossRef] [PubMed]

25. Jacukowicz-Sobala, I.; Ocinski, D.; Mazur, P.; Stanisławska, E.; Kociołek-Balawejder, E. Cu(II)-Fe(III) oxide doped anion exchangers-Multifunctional composites for arsenite removal from water via As(III) adsorption and oxidation. J. Hazard. Mater. 2020. [CrossRef] [PubMed]

26. Xu, W.; Wang, J.; Wang, L.; Sheng, G.; Liu, J.; Yu, H.; Huang, X.-J. Enhanced arsenic removal from water by hierarchically porous $\mathrm{CeO}_{2}-\mathrm{ZrO}_{2}$ nanospheres: Role of surface- and structure-dependent properties. J. Hazard. Mater. 2013, 260, 498-507. [CrossRef] [PubMed]

27. Geim, A.K.; Novoselov, K.S. The rise of graphene. Nat. Mater. 2007, 6, 183-191. [CrossRef]

28. Avouris, P.; Dimitrakopoulos, C. Graphene: Synthesis and applications. Mater Today 2012, 15, 86-97. [CrossRef]

29. Weiss, N.O.; Zhou, H.; Liao, L.; Liu, Y.; Jiang, S.; Huang, Y.; Duan, X. Graphene: An Emerging Electronic Material. Adv. Mater. 2012, 24, 5782-5825. [CrossRef]

30. Kemp, K.C.; Seema, H.; Saleh, M.; Le, N.H.; Mahesh, K.; Chandra, V.; Kim, K.S. Environmental applications using graphene composites: Water remediation and gas adsorption. Nanoscale 2013, 5, 3149-3171. [CrossRef]

31. Sundramoorthy, A.K.; Gunasekaran, S. Applications of graphene in quality assurance and safety of food. TrAC Trends Anal. Chem. 2014, 60, 36-53. [CrossRef]

32. Novoselov, K.S.; Geim, A.K.; Morozov, S.V.; Jiang, D.; Zhang, Y.; Dubonos, S.V.; Grigorieva, I.V.; Firsov, A.A. Electric field effect in atomically thin carbon films. Science 2004, 306, 666-669. [CrossRef] 
33. Zhang, K.; Dwivedi, V.; Chi, C.; Wu, J. Graphene oxide/ferric hydroxide composites for efficient arsenate removal from drinking water. J. Hazard. Mater. 2010, 182, 162-168. [CrossRef] [PubMed]

34. Katsoyiannis, I.A.; Zouboulis, A.I. Removal of arsenic from contaminated water sources by sorption onto iron-oxide-coated polymeric materials. Water Res. 2002, 36, 5141-5155. [CrossRef]

35. Luo, X.; Wang, C.; Luo, S.; Dong, R.; Tu, X.; Zeng, G. Adsorption of As (III) and As (V) from water using magnetite $\mathrm{Fe}_{3} \mathrm{O}_{4}$-reduced graphite oxide- $\mathrm{MnO}_{2}$ nanocomposites. Chem. Eng. J. 2012, 187, 45-52. [CrossRef]

36. Simeonidis, K.; Gkinis, T.; Tresintsi, S.; Martinez-Boubeta, C.; Vourlias, G.; Tsiaoussis, I.; Stavropoulos, G.; Mitrakas, M.; Angelakeris, M. Magnetic separation of hematite-coated $\mathrm{Fe}_{3} \mathrm{O}_{4}$ particles used as arsenic adsorbents. Chem. Eng. J. 2011, 168, 1008-1015. [CrossRef]

37. Cui, H.; Li, Q.; Gao, S.; Shang, J.K. Strong adsorption of arsenic species by amorphous zirconium oxide nanoparticles. J. Ind. Eng. Chem. 2012, 18, 1418-1427. [CrossRef]

38. Luo, X.; Wang, C.; Wang, L.; Deng, F.; Luo, S.; Tu, X.; Au, C. Nanocomposites of graphene oxide-hydrated zirconium oxide for simultaneous removal of As(III) and As(V) from water. Chem. Eng. J. 2013, 220, 98-106. [CrossRef]

39. Gallios, G.; Tolkou, A.; Katsoyiannis, I.; Stefusova, K.; Vaclavikova, M.; Deliyanni, E. Adsorption of Arsenate by Nano Scaled Activated Carbon Modified by Iron and Manganese Oxides. Sustainability 2017, 9, 1684. [CrossRef]

40. Manna, B.R.; Dey, S.; Debnath, S.; Ghosh, U.C. Removal of arsenic from groundwater using crystalline hydrous ferric oxide (CHFO). Water Qual. Res. J. Can. 2003, 38, 93-210. [CrossRef]

41. Manna, B.R.; Dasgupta, M.; Ghosh, U.C. Crystalline hydrous titanium (IV) oxide (CHTO): An arsenic (III) scavenger from natural water. J. Water Supply Res. Tehnol. 2004, 53, 483-495. [CrossRef]

42. Kanel, S.R.; Manning, B.; Charlet, L.; Choi, H. Removal of arsenic(III) from groundwater by nanoscale zero-valent iron. Environ. Sci. Technol. 2005, 39, 1291-1298. [CrossRef]

43. Pena, M.E.; Korfiatis, G.P.; Patel, M.; Lippincott, L.; Meng, X. Adsorption of As (V) and As (III) by nanocrystalline titanium dioxide. Water Res. 2005, 39, 2327-2337. [CrossRef]

44. Manna, B.; Ghosh, U.C. Adsorption of arsenic from aqueous solution on synthetic hydrous stannic oxide. J. Hazard. Mater. 2007, 144, 522-531. [CrossRef]

45. Deliyanni, E.A.; Bakoyannakis, D.N.; Zouboulis, A.I.; Matis, K.A. Sorption of As (V) ions by akaganéite-type nanocrystals. Chemosphere 2003, 50, 155-163. [CrossRef]

46. U.S. Environmental Protection Agency. Chromium in Drinking Water; EPA: Washington, DC, USA, 2010.

47. U.S. Environmental Protection Agency; IRIS. Toxicological Review of Hexavalent Chromium; EPA: Washington, DC, USA, 2010.

48. World Health Organization. Chromium in Drinking-Water; WHO: Geneva, Switzerland, 2003.

49. U.S. California Environmental Protection Agency. Chromium-6 Drinking Water MCL; U.S. California Environmental Protection Agency: Sacramento, CA, USA, 2014.

50. Sharma, S.K.; Petrusevski, B.; Amy, G. Chromium removal from water: A review. J. Water Supply Res. Tehnol. 2008, 57, 541-553. [CrossRef]

51. Rai, D.; Eary, L.E.; Zachara, J.M. Environmental chemistry of chromium. Sci. Total. Environ. 1989, 86, 15-23. [CrossRef]

52. Mahmood, T.; Saddique, M.T.; Naeem, A.; Mustafa, S.; Hussain, J.; Dilara, B. Cation exchange removal of Zn from aqueous solution by NiO. J. Non Cryst. Solids. 2011, 357, 1016-1020. [CrossRef]

53. Behnajady, M.A.; Bimeghdar, S. Synthesis of mesoporous $\mathrm{NiO}$ nanoparticles and their application in the adsorption of $\mathrm{Cr}(\mathrm{VI})$. Chem. Eng. J. 2014, 239, 105-113. [CrossRef]

54. Li, L.; Fan, L.; Sun, M.; Qiu, H.; Li, X.; Duan, H.; Luo, C. Adsorbent for chromium removal based on graphene oxide functionalized with magnetic cyclodextrin-chitosan. Colloids Surf. B Biointerfaces. 2013, 107, 76-83. [CrossRef]

55. Mura, P. Analytical techniques for characterization of cyclodextrin complexes in aqueous solution: A review. J. Pharm. Biomed. Anal. 2014, 101, 238-250. [CrossRef]

56. Samuel, M.S.; Bhattacharya, J.; Raj, S.; Santhanam, N.; Singh, H.; Singh, N.D.P. Efficient removal of Chromium (VI) from aqueous solution using chitosan grafted graphene oxide (CS-GO) nanocomposite. Int. J. Biol. Macromol. 2019, 121, 285-292. [CrossRef] 
57. Setshedi, K.Z.; Bhaumik, M.; Onyango, M.S.; \& Maity, A. High-performance towards Cr (VI) removal using multi-active sites of polypyrrole-graphene oxide nanocomposites: Batch and column studies. Chem. Eng. J. 2015, 262, 921-931. [CrossRef]

58. Hou, T.; Kong, L.; Guo, X.; Wu, Y.; Wang, F.; Wen, Y.; Yang, H. Magnetic ferrous-doped graphene for improving Cr (VI) removal. Mater. Res. Express 2016, 3, 045006. [CrossRef]

59. Liu, H.; Zhang, F.; Peng, Z. Adsorption mechanism of Cr(VI) onto GO/PAMAMs composites. Sci. Rep. 2019, 9, 3663. [CrossRef] [PubMed]

60. Dong, A.; Xie, J.; Wang, W.; Yu, L.; Liu, Q.Y. A novel method for amino starch preparation and its adsorption for $\mathrm{Cu}(\mathrm{II})$ and $\mathrm{Cr}(\mathrm{VI})$. J. Hazard. Mater. 2010, 181, 448-454. [CrossRef] [PubMed]

61. Alvarez, G.S.; Foglia, M.L.; Camporotondi, D.E.; Tuttolomondo, M.V.; Desimone, M.F.; Diaz, L.E. A functional material that combines the $\mathrm{Cr}(\mathrm{VI})$ reduction activity of Burkholderia sp. with the adsorbent capacity of sol-gel materials. J. Mater. Chem. 2011, 21, 6359-6364. [CrossRef]

62. Asuha, S.; Zhou, X.G.; Zhao, S. Adsorption of methyl orange and $\mathrm{Cr}(\mathrm{VI})$ on mesoporous $\mathrm{TiO}_{2}$ prepared by hydrothermal method. J. Hazard. Mater. 2010, 181, 204-210. [CrossRef]

63. RajivGandhi, M.; Viswanathan, N.; Meenakshi, S. Preparation and application of alumina/chitosan biocomposite. Int. J. Biol. Macromol. 2010, 47, 146-154. [CrossRef]

64. Bishnoi, N.R.; Bajaj, M.; Sharma, N.; Gupta, A. Adsorption of Cr(VI) on activated rice husk carbon and activated alumina. Bioresour. Technol. 2004, 91, 305-307. [CrossRef]

65. Sun, Y.; Ding, C.; Cheng, W.; Wang, X. Simultaneous adsorption and reduction of U(VI) on reduced graphene oxide-supported nanoscale zerovalent iron. J. Hazard. Mater. 2014, 280, 399-408. [CrossRef]

66. Fan, F.L.; Qin, Z.; Bai, J.; Rong, W.D.; Fan, F.Y.; Tian, W.; Wu, X.L.; Wang, Y.; Zhao, L. Rapid removal of uranium from aqueous solutions using magnetic Fe3O4@SiO2 composite particles. J. Environ. Radioact. 2012, 106, 40-46. [CrossRef]

67. Chen, S.; Hong, J.; Yang, H.; Yang, J. Adsorption of uranium (VI) from aqueous solution using a novel graphene oxide-activated carbon felt composite. J. Environ. Radioact. 2013, 126, 253-258. [CrossRef]

68. World Health Organization. Uranium in Drinking Water; WHO: Geneva, Switzerland, 2012.

69. Katsoyiannis, I.A.; Althoff, W.H.; Bartel, H.; Jekel, M. The effect of groundwater composition on uranium(VI) sorption onto bacteriogenic iron oxides. Water Res. 2006, 40, 3646-3652. [CrossRef]

70. Barton, C.S.; Stewart, D.I.; Morris, K.; Bryant, D.E. Performance of three resin-based materials for treating uranium-contaminated groundwater within a PRB. J. Hazard. Mater. 2004, 116, 191-204. [CrossRef]

71. Gu, B.; Ku, Y.K.; Jardine, P.M. Sorption and binary exchange of nitrate, sulfate, and uranium on an anion-exchange resin. Environ. Sci. Technol. 2004, 38, 3184-3188. [CrossRef]

72. Favre-Reguillon, A.; Lebuzit, G.; Murat, D.; Foos, J.; Mansour, C.; Draye, M. Selective removal of dissolved uranium in drinking water by nanofiltration. Water Res. 2008, 42, 1160-1166. [CrossRef]

73. Lin, K.L.; Chu, M.L.; Shieh, M.C. Treatment of uranium containing effluents with reverse osmosis process. Desalination 1987, 61, 125-136. [CrossRef]

74. Raff, O.; Wilken, R.D. Removal of dissolved uranium by nanofiltration. Desalination 1999, 122, 147-150. [CrossRef]

75. Das, D.; Sureshkumar, M.K.; Koley, S.; Mithal, N.; Pillai, C.G.S. Sorption of uranium on magnetite nanoparticles. J. Radioanal. Nucl. Chem. 2010, 285, 447-454. [CrossRef]

76. Ching-kuo, D.H.; Langmuir, D. Adsorption of uranyl onto ferric oxyhydroxides: Application of the surface complexation site-binding model. Geochim. Cosmochim. Acta 1985, 49, 1931-1941. [CrossRef]

77. Katsoyiannis, I.A. Carbonate effects and $\mathrm{pH}$-dependence of uranium sorption onto bacteriogenic iron oxides: Kinetic and equilibrium studies. J. Hazard. Mater. 2007, 139, 31-37. [CrossRef] [PubMed]

78. Wazne, M.; Korfiatis, G.P.; Meng, X. Carbonate effects on hexavalent uranium adsorption by iron oxyhydroxide. Environ. Sci. Technol. 2003, 37, 3619-3624. [CrossRef]

79. Li, Z.; Chen, F.; Yuan, L.; Liu, Y.; Zhao, Y.; Chai, Z. Uranium (VI) adsorption on graphene oxide nanosheets from aqueous solutions. Chem. Eng. 2012, 210, 539-546. [CrossRef]

80. Tan, L.; Wang, Y.; Liu, Q.; Wang, J.; Jing, X.; Liu, L.; Shi, W. Enhanced adsorption of uranium (VI) using a three-dimensional layered double hydroxide/graphene hybrid material. Chem. Eng. 2015, 259, 752-760. [CrossRef] 
81. Liu, S.; Li, S.; Zhang, H.; Wu, L.; Sun, L.; Ma, J. Removal of uranium(VI) from aqueous solution using graphene oxide and its amine-functionalized composite. J. Radioanal. Nucl. Chem. 2016, 309, 607-614. [CrossRef]

82. Misaelides, P.; Godelitsas, A.; Filippidis, A.; Charistos, D.; Anousis, I. Thorium and uranium uptake by natural zeolitic materials. Sci. Total Environ. 1995, 173, 237-246. [CrossRef]

83. Chen, C.; Wang, J. Uranium removal by novel graphene oxide-immobilized Saccharomyces cerevisiae gel beads. J. Environ. Radioact. 2016, 162, 134-145. [CrossRef]

84. Mohamud, H.; Ivanov, P.; Russell, B.C.; Regan, P.H.; Ward, N.I. Selective sorption of uranium from aqueous solution by graphene oxide-modified materials. J. Radioanal. Nucl. Chem. 2018, 316, 839-848. [CrossRef]

85. Liu, S.; Ouyang, J.; Luo, J.; Sun, L.; Huang, G.; Ma, J. Removal of uranium(VI) from aqueous solution using graphene oxide functionalized with diethylenetriaminepentaacetic phenylenediamine. J. Nucl. Sci. Technol. 2018, 55, 781-791. [CrossRef]

86. Yang, A.; Zhu, Y.; Li, P.; Huang, C.P. Preparation of a magnetic reduced-graphene oxide/tea waste composite for high-efficiency sorption of uranium. Sci. Rep. 2019, 9, 6471. [CrossRef]

87. Han, R.; Zou, W.; Wang, Y.; Zhu, L. Removal of uranium(VI) from aqueous solutions by manganese oxide coated zeolite: Discussion of adsorption isotherms and pH effect. J. Environ. Radioact. 2007, 93, 127-143. [CrossRef]

88. Donat, R. The removal of uranium (VI) from aqueous solutions onto natural sepiolite. J. Chem. Thermodyn. 2009, 41, 829-835. [CrossRef]

89. Humelnicu, D.; Popovici, E.; Dvininov, E.; Mita, C. Study on the retention of uranyl ions on modified clays with titanium oxide. J. Radioanal. Nucl. Chem. 2009, 279, 131-136. [CrossRef]

90. Wang, J.S.; Peng, R.T.; Yang, J.H.; Liu, Y.C.; Hu, X.J. Preparation of ethylenediamine-modified magnetic chitosan complex for adsorption of uranyl ions. Carbohydr. Polym. 2011, 84, 1169-1175. [CrossRef]

91. Yusan, S.; Erenturk, S. Sorption behaviors of uranium (VI) ions on $\alpha$-FeOOH. Desalination 2011, 269, 58-66. [CrossRef]

92. Dimiropoulos, V.; Katsoyiannis, I.A.; Zouboulis, A.I.; Noli, F.; Simeonidis, K.; Mitrakas, M. Enhanced U(VI) removal from drinking water by nanostructured binary Fe/Mn oxy-hydroxides. J. Water Process. Eng. 2015, 7, 227-236. [CrossRef] 